\title{
TRANSFORMASI LEMBAGA SWADAYA MASYARAKAT MENUJU WIRAUSAHA SOSIAL: STUDI KASUS KOMUNITAS FILM AYOFEST
}

\author{
Kus Sudarsono
}

\begin{abstract}
Abstrak: Lembaga Swadaya Masyarakat (LSM) memberikan manfaat yang banyak dan beragam bagi kehidupan masyarakat luas, mulai dari bidang pendidikan, kesejahteraan masyarakat, kesehatan, perbaikan lingkungan hidup dan lain sebagainya. Tantangan yang dihadapi oleh LSM adalah ketergantungan pada lembaga donor yang biasanya berasal dari luar negeri, serta tren menurunnya pembiayaan lembaga donor bagi LSM di Indonesia. Tanpa adanya pendanaan dari lembaga donor, maka kegiatan LSM tersebut akan berkurang, bahkan berhenti. Social entrepreneur merupakan sebuah format bisnis yang dapat dipergunakan LSM untuk dapat menjadi mandiri, meninggalkan ketergantungan terhadap lembaga donor. Penyaluran dana Corporate Social Responsibility melalui Social entrepreneur merupakan alternatif pendanaan untuk sebuah pemberdayaan masyarakat yang berkelanjutan serta menghilangkan ketergantungan pada sumber donor dari luar negeri. Komunitas Ayofest merupakan komunitas yang memfokuskan diri pada pendidikan sinematografi pada remaja yang kurang mampu sebagai life skill di kemudian hari. Tulisan ini menggunakan metode kualitatif melalui studi pustaka dan wawancara.
\end{abstract}

Keywords: Social Entrepreneur, pendidikan sinematografi, Lembaga Swadaya Masyarakat, remaja 


\section{Pendahuluan}

Hadirnya 10 stasiun televisi nasional di Indonesia, berkembangnya saluran televisi berbayar, serta lebih dari 200 stasiun televisi daerah di Indonesia, merupakan bukti bahwa lapangan kerja di bidang sinematografi sangat luas. Selain televisi, industri film layar lebar, corporate video, iklan, video musik, video pernikahan dan banyak bidang lain yang juga membutuhkan kemampuan sinematografi.

Hambatan yang terjadi untuk mendapatkan pendidikan sinematografi adalah mahalnya biaya pembelian alat dan jumlah intitusi pendidikan sinematografi yang terbatas. Hambatan ini akan menjadi lebih berat bagi mereka yang berasal dari keluarga yang berstatus ekonomi menengah ke bawah. Sedangkan di sisi lain, pendidikan sinematografi sendiri bisa membantu mereka mendapatkan skill yang di kemudian hari menjadi lahan penghasilan secara profesional.

Berdasarkan data Badan Pusat Statistik pada tahun 2010, jumlah penduduk Indonesia adalah 237.641.326 jiwa dengan didominasi oleh usia muda pada kelompok umur 10-19 tahun yakni sebesar 43.551.815 jiwa. Sangatlah penting bagi semua orang untuk memberikan life skill bagi remaja Indonesia demi mempersiapkan masa depan mereka.

\section{Pembentukan Komunitas AYOFest}

AYOFest didirikan oleh 4 profesional yang berkarir di bidang sinematografi yang berbeda-beda. Pendiri AYOFest adalah Zaqia Ramallah (Guru/dosen videografi), Sarnizia (Karyawan TV Swasta), Bisma FS (Fotografer, dosen) dan Kus Sudarsono (Videographer, dosen). AYOFest dibentuk dengan tujuan mendidik remaja Indonesia, terutama mereka yang kurang mampu untuk dapat mempelajari sinematografi secara mudah dan sedapat mungkin gratis.

AYOFest didirikan sejak September 2012 dengan mengandalkan waktu luang para pendirinya, biaya dan peralatan pribadi masing-masing. Nama AYOFest sendiri merupakan kependekan dari INDONESIA YOUNG FILM FESTIVAL. Pada awal pendirian, AYOFest melihat kegiatan festival film bagi remaja masih sangat sedikit dan dilakukan secara sporadis, hanya satu atau dua festival film yang secara konsisten melakukan festival film setiap tahun yang ditujukan bagi remaja, khususnya pelajar SMA/SMK. AYOFest memandang festival film sebagai sebuah kegiatan yang memiliki potensi publikasi dan potensi pendapatan melalui sponsorship. AYOFest melihat 
potensi penyelenggaraan kegiatan festival film mampu menciptakan keuntungan yang akan dialokasikan untuk edukasi sinematografi remaja kurang mampu.

Sebagai langkah awal, AYOFest memutuskan bahwa edukasi sinematografi yang murah hanya dapat dilakukan dengan pendidikan secara daring (online) yang dapat diakses dengan mudah dan relatif murah. Pendidikan sinematografi ini dilakukan melalui pembuatan situs www.ayofest. com dan channel YouTube, melalui dua situs ini, AYOFest membuat beberapa tutorial yang menjelaskan mengenai hal-hal yang mendasar mengenai sinematografi. Kemudian dibuat juga media sosial melalui Facebook dan Twitter yang populer di kalangan remaja.

\section{Kolaborasi}

Keterbatasan pendanaan bagi AYOFest membuat AYOFest harus melakukan kolaborasi sebagai cara yang efektif dengan pihak

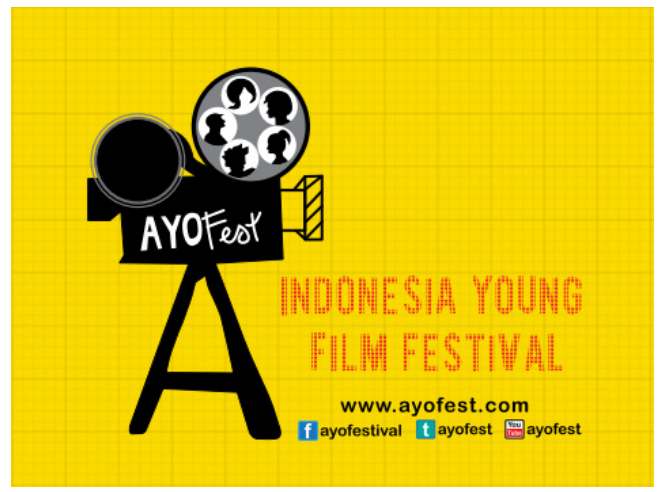

Gambar 1. Logo AYOFest

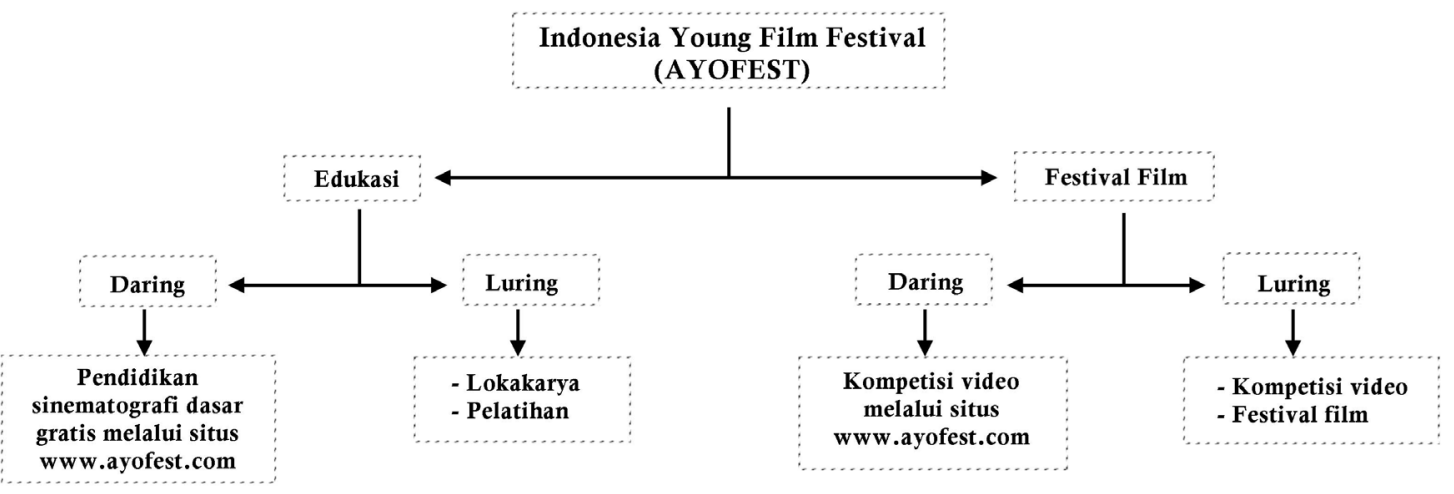

Diagram 1. Skema kegiatan-kegiatan AYOFest 
lain dalam mengatasi hal tersebut.

Dalam bukunya Partnership Marketing, Ron Kunitzky mendefinisikan pemasaran persekutuan sebagai: Sebuah kolaborasi dari dua atau lebih organisasi-organisasi dengan keinginan untuk membangun sebuah program pemasaran jangka pendek maupun jangka panjang yang didesain untuk menjangkau tujuan bisnis masing-masing pihak. Kebutuhan untuk sebuah program pemasaran persekutuan dimana sebuah organisasi dapat mencapai tujuan-tujuan mereka dengan mengungkit kekuatan komplementar dari organisasi lain dalam mengejar basis konsumen yang mirip (Kunitzky, 2011, p.3).

Berikut adalah hasil dari kegiatan AYOFest dengan beberapa pihak ketiga.

\section{Kolaborasi dengan Indo- nesia Corruption Watch (ICW) dalam kegiatan 'Fes- tival Film Jujur'}

Partner pertama AYOFest adalah ICW yang memiliki target audience yang sama, yaitu para remaja Indonesia. AYOFest melakukan kegiatan ini pada awal 2013 dengan kegiatan puncak pada Hari Anti Korupsi Se-Dunia yang

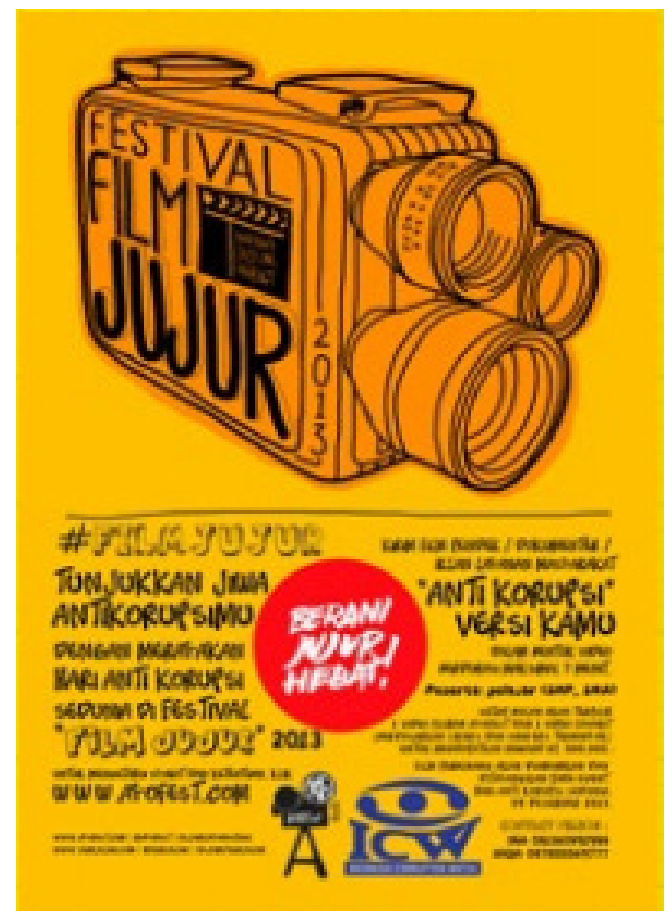

Gambar 2. Poster Festival Film Jujur 2013

jatuh pada tanggal 9 Desember 2013.

\section{Kolaborasi dengan Wahana Visi Indonesia}

Kolaborasi kedua dilakukan dengan Lembaga Swadaya Masyarakat Wahana Visi Indonesia (World Vision Indonesia), LSM ini memiliki basis komunitas yang mirip dengan target misi sosial AYOFest yaitu remaja yang kurang mampu. Kolaborasi ini berjalan cukup lama, mulai dari September 2013 hingga saat ini. AYOFest beberapa kali diundang sebagai tenaga pengajar dalam pelatihan sinematografi yang dilaksanakan oleh WVI.

Pelatihan ini telah menghasilkan 
beberapa video berupa iklan, drama, dokumenter dan video musik. Hampir 150 remaja telah mengikuti pelatihan ini melalui beberapa kegiatan pelatihan. Pelatihan ini dilakukan berupa rangkaian kegiatan, dilakukan setiap hari

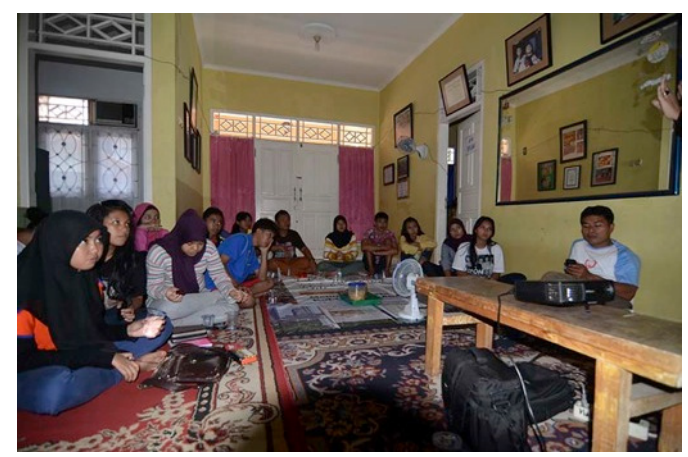

Gambar 3. Pelatihan sinematografi di Kramat Jati

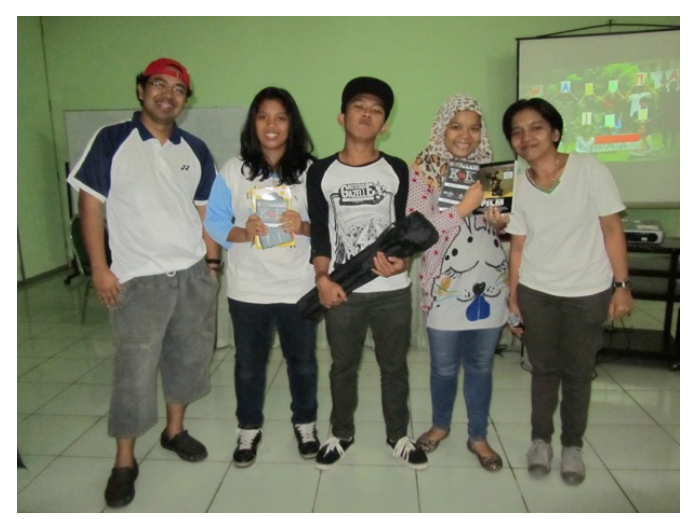

Gambar 4. Pelatihan sinematografi bersama WVI, Cibubur

minggu selama 5 pertemuan atau dilakukan secara intensif selama 2 hari penuh.

\section{Analisis Hasil Kegiatan AYOFest}

Kegiatan AYOFest selama hampir tiga tahun berjalan dengan lancar dengan segala keterbatasan yang ada. Namun ada beberapa hal yang harus dicermati dari pelaksanaan kegiatan AYOFest antara lain:

\section{Pembuatan video tutorial secara daring kurang ber- pengaruh}

Video tutorial mengenai sinematografi sendiri sudah sangat banyak tersedia pada situs YouTube, Vimeo maupun beberapa situs lain, namun sebagian besar masih berbahasa asing (Inggris). AYOFest sendiri menawarkan video tutorial dengan basis bahasa Indonesia yang mudah dipahami remaja. Namun, melalui hasil diskusi dengan peserta pelatihan, terungkap kecilnya pengaruh video tutorial tersebut dengan keinginan membuat atau belajar pembuatan video. Hal yang paling berpengaruh justru adalah kegiatan luring (offline) dimana mereka bertemu dengan teman-teman yang memiliki hasrat yang sama. Tanpa adanya keberadaan teman, hampir tidak mungkin mereka membuat video.

\section{Festival Film tidak sesuai dengan tujuan AYOFest}

Festival Film adalah kegiatan yang menarik bagi banyak pihak maupun sponsor, namun kegiatan ini insidentil, seremonial dan tidak memberikan pengetahuan dan skill sinematografi pada remaja secara langsung, terlebih tidak dapat secara spesifik menguntungkan mereka yang secara ekonomi tidak be- 
runtung. Sehingga, tujuan dari pembentukan AYOFest sendiri kurang tercapai melalui kegiatan Festival Film sendiri.

\section{Pendanaan LSM yang cend- erung terus menurun}

AYOFest selalu mencari sumber pendanaan dari banyak pihak lain, ICW mempertemukan AYOFest dengan YLBHI, KPK dan LSM Rumah Kebangsaan. Hasil berbincang dengan beberapa tokoh seperti Bapak Teten Masduki (Rumah Kebangsaan) dan Bapak Alvon Kurnia Palma (Ketua YLBHI), dapat disimpulkan bahwa negara donor atau pihak donor dari luar negeri cenderung mengurangi donasi mereka ke Indonesia antara lain karena Indonesia sudah dipandang sebagai negara yang tidak miskin lagi. Para donor akan cenderung mendonasikan dana mereka ke negara-negara lain yang lebih miskin. Wawancara dengan pihak ICW Ibu Ilin Deta Arnasari mengungkapkan ICW sendiri di masa mendatang akan lebih menggali potensi sumber dana dari masyarakat luas (crowdfunding) untuk mengatasi pengurangan donasi dari lembaga donor.

\section{Pendanaan melalui Corpo- rate Social Responsibility (CSR) yang terbatas}

Dana CSR merupakan sumber pendanaan yang dapat diperoleh LSM dari perusahaan swasta besar. AYOFest juga mencoba mengakses beberapa sumber untuk dapat memperoleh pendanaan CSR. Namun akses untuk memperoleh pendanaan CSR masih sulit, terutama bagi LSM kecil yang belum memiliki badan hukum. LSM tertentu bahkan tidak dapat mengelola dana CSR dikarenakan harus menghindari potensi conflict of interest, hal ini dialami oleh LSM ICW, YLBHI dan beberapa LSM lain.

\section{Pembentukan Wirausaha Sosial}

AYOFest saat ini sedang melakukan perubahan pendekatan untuk dapat melanjutkan kegiatan pendidikan sinematografi secara mandiri dan berkesinambungan. Pembentukan wirausaha sosial menjadi salah satu hal yang harus dilakukan LSM agar dapat lepas dari ketergantungan pada donor.

\section{AYOFest sebagai wirausaha sosial}

Borzaga dan Defourny (2001) dalam bukunya, The Emergence of Social Enterprise, yang mendefinisikan wirausaha sosial sebagai sebuah organisasi yang dengan gamblang bertujuan agar dapat bermanfaat bagi komunitas, dibentuk oleh sekelompok penduduk/ masyarakat dan membatasi kepentingan material maupun dana investor sampai batas tertentu saja.

Pada awal pendiriannya, AYOFest 


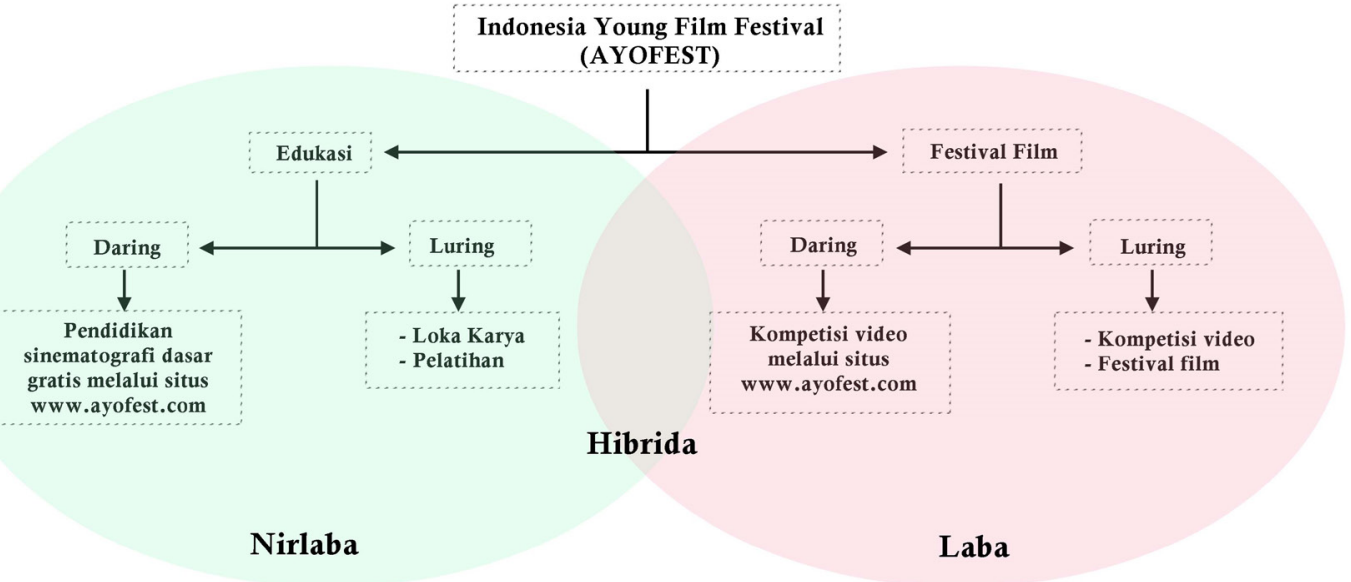

Diagram 2. Skema awal pendapatan AYOFest

mempergunakan pendekatan hibri- komersial melalui pembuatan kegiada untuk menjalankan misinya. tan festival film. Pendekatan hibrida

Pada pendekatan hibrida, pendanaan sisi edukasi didukung oleh pendapatan ini membuat edukasi sinematografi bergantung pada pendapatan komer-

\section{Sumber Dana}

Hibah, Lembaga Donor, Budget Pemasaran Produk/Jasa

\section{Kegiatan Festival Film yang dikelola AYOFest}
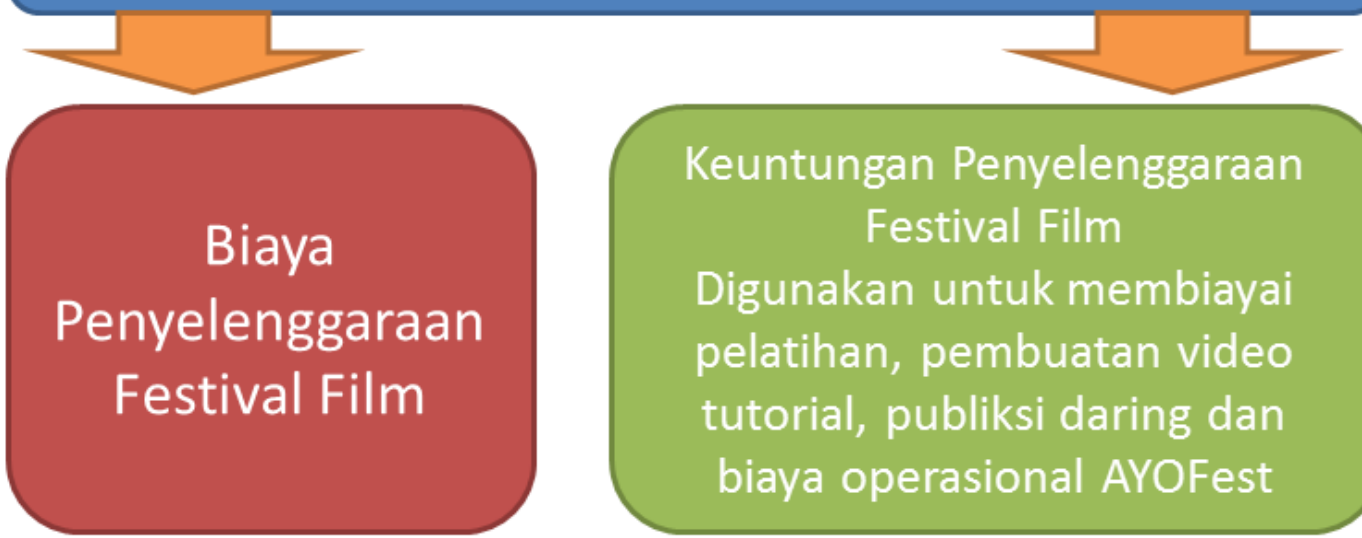

Keuntungan Penyelenggaraan

Festival Film

Digunakan untuk membiayai

pelatihan, pembuatan video

tutorial, publiksi daring dan

biaya operasional AYOFest

Diagram 3. Skema awal aliran dana untuk membiayai edukasi sinematografi 
sial penyelenggaraan festival film.

Terlihat pada skema ini, AYOFest mengandalkan kegiatan komersial penyelenggaraan festival film untuk dapat menjalankan sisi sosial AYOFest dalam mengedukasi remaja kurang mampudalampendidikansinematografi.

Seiring berkembangnya network AYOFest, kolaborasi dengan Wahana Visi Indonesia (WVI) sendiri berjalan di luar konsep awal yang dilakukan AYOFest, namun AYOFest merasa hal ini justru mendukung misi edukasi dari
AYOFest secara langsung. Sebagai sebuah LSM yang fokus pada anak dan remaja urban yang kurang mampu secara ekonomi, WVI, memiliki pendanaan untuk melakukan beberapa kegiatan edukasi sinematografi dalam kalender kegiatan mereka. Namun, LSM seperti WVI juga menghadapi keterbatasan pendanaan yang sangat tergantung pada donasi dari luar Indonesia. Donasi semacam ini yang berpotensi akan terus menurun seiring dengan meningkatnya ekonomi Indonesia di mata dunia.

Untuk menghindari hal tersebut, skema pendekatan hibrida AYOFest

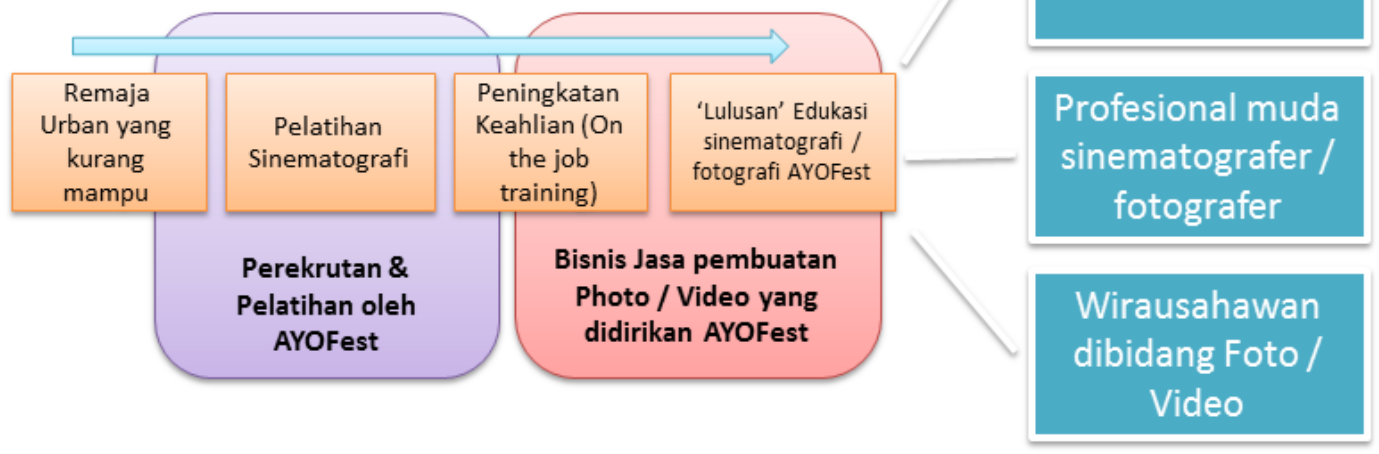

Diagram 4. Skema ideal wirausaha sosial AYOFest

harus diubah menjadi skema sebuah wirausaha sosial yang lebih mengarah pada pendekatan bisnis atau wirausaha.

Skema ini masih berada pada tahap ideasi, sehingga belum pernah diterapkan secara nyata oleh AYOFest. Perubahan utama adalah pendirian sebuah bisnis murni dibidang sinematografi dan fotografi. Pada skema ini, para remaja yang kurang mampu akan mendapatkan pelatihan secara gratis dari AYOFest yang kemudian menempatkan mereka pada kegiatan inti bisnis yang nyata sebagai crew atau sebagai 
profesional dibidang sinematografi. Diharapkan, para remaja ini kemudian dapat 'lulus' dari pelatihan AYOFest sebagai profesional muda di bidang sinematografi atau dapat menjadi seorang wirausahawan di bidang yang sama. Melalui pembentukan wirausaha sosial, diharapkan perubahan sumber pendanaan yang awalnya bergantung pada lembaga donor, beru-

\begin{tabular}{|c|c|c|c|c|c|c|}
\hline \multirow{2}{*}{$\begin{array}{c}\text { Key Partners } \\
\text { LSM Lain, Komunitas } \\
\text { Remaja }\end{array}$} & \multirow{2}{*}{\multicolumn{2}{|c|}{$\begin{array}{l}\text { Key Activities } \\
\text { Memberikan pelatihan, } \\
\text { pembuatan modul, } \\
\text { perekrutan remaja }\end{array}$}} & \multirow{3}{*}{\multicolumn{2}{|c|}{$\begin{array}{c}\text { Value Propositions } \\
\text { Memberikan } \\
\text { pendidikan } \\
\text { sinematografi } \\
\text { secara gratis bagi } \\
\text { remaja yang } \\
\text { kurang mampu }\end{array}$}} & \multirow{3}{*}{$\begin{array}{l}\text { Social Media } \\
\text { Mobile Hotline }\end{array}$} & \multirow{3}{*}{$\begin{array}{c}\text { Customer Segments } \\
\text { Remaja usia 17-21 } \\
\text { tahun, urban, } \\
\text { tertarik dengan } \\
\text { sinematografi / } \\
\text { Fotografi }\end{array}$} \\
\hline & & & & & & \\
\hline \multirow{2}{*}{$\begin{array}{l}\text { Komunitas Profesional } \\
\text { sinematografi dan } \\
\text { fotografi }\end{array}$} & \multicolumn{2}{|c|}{$\begin{array}{l}\text { Pemasaran, pelatihan, } \\
\text { liputan event, } \\
\text { pembuatan portofolio }\end{array}$} & & & & \\
\hline & \multicolumn{2}{|c|}{ Key Resources } & \multirow{2}{*}{\multicolumn{2}{|c|}{$\begin{array}{c}\text { Menyediakan jasa } \\
\text { fotografi dan videografi } \\
\text { pada masyarakat luas }\end{array}$}} & Channels & \multirow[b]{2}{*}{$\begin{array}{l}\text { Masyarakat luas yang } \\
\text { membutuhkan jasa } \\
\text { videografi, fotografi dan } \\
\text { pelatihan sinematografi }\end{array}$} \\
\hline \multirow{2}{*}{$\begin{array}{l}\text { Lembaga pendidikan } \\
\text { lain } \\
\text { Perusahaan besar } \\
\text { penyedia dana CSR }\end{array}$} & \multicolumn{2}{|c|}{$\begin{array}{c}\text { Tenaga Pengajar, } \\
\text { Pusat Pelatihan, } \\
\text { Peralatan Mengajar }\end{array}$} & & & $\begin{array}{c}\text { Online, pusat } \\
\text { pelatihan, LSM lair }\end{array}$ & \\
\hline & \multicolumn{2}{|c|}{$\begin{array}{c}\text { Karyawan inti (foto } \\
\text { dan video), tenaga } \\
\text { pemasaran }\end{array}$} & \multicolumn{2}{|c|}{$\begin{array}{l}\text { Menyediakan pelatihan } \\
\text { fotografi dan videografi } \\
\text { bagi perusahaan, } \\
\text { karyawan dan individu } \\
\text { yang memerlukan }\end{array}$} & $\begin{array}{c}\text { Kantor, event, } \\
\text { pelatihan }\end{array}$ & $\begin{array}{l}\text { Perusahaan Besar yang } \\
\text { memiliki dana CSR dan } \\
\text { pembimbing bisnis }\end{array}$ \\
\hline \multicolumn{6}{|l|}{ Cost Structure } & \\
\hline \multicolumn{2}{|c|}{$\begin{array}{l}\text { Biaya pengajar, modul, } \\
\text { ruang kelas, biaya belajar } \\
\text { mengajar, peralatan } \\
\text { presentasi dan lain-lain }\end{array}$} & \multicolumn{2}{|c|}{$\begin{array}{c}\text { Overhead perusahaan (fixed \& } \\
\text { variable cost), marketing cost, } \\
\text { investment cost, sewa kantor } \\
\text { dan ruangan pelatihan }\end{array}$} & \multicolumn{2}{|c|}{$\begin{array}{l}\text { Pelatihan bagi pihak lain } \\
\text { diluar Remaja (swasta, } \\
\text { lembaga pemerintahan, } \\
\text { individual, dan lain-lain }\end{array}$} & $\begin{array}{c}\text { Keuntungan dari penyediaan } \\
\text { barang dan jasa (foto dan } \\
\text { video) } \\
\text { Dana CSR dari perusahaan } \\
\text { besar }\end{array}$ \\
\hline
\end{tabular}

Diagram 5. Business model canvas AYOFest

bah menjadi sebuah bisnis independen yang bermanfaat bagi masyarakat luas.

Dari diagram business model canvas di atas, terlihat bahwa AYOFest akan menjalankan sisi bisnis dan sisi sosial pada waktu yang bersamaan. Pada model ini, kedua sisi saling menunjang satu sama lain, dimana sisi sosial menyediakan tenaga kerja untuk sisi bisnis, sedangkan sisi bisnis memberikan keuntungan yang kemudian digunakan untuk memperkuat atau mem- perluas sisi sosial edukasi AYOFest.

\section{Peranan Corporate Social Responsibility dalam men- dukung wirausaha sosial}

Wirausaha sosial tetap membutuhkan pendanaan awal untuk menjalankan sebuah bisnis murni, dana awal pendirian bisa diperoleh melalui dana CSR perusahaan besar, lebih dari itu, perusahaan besar tersebut bisa menjadi 


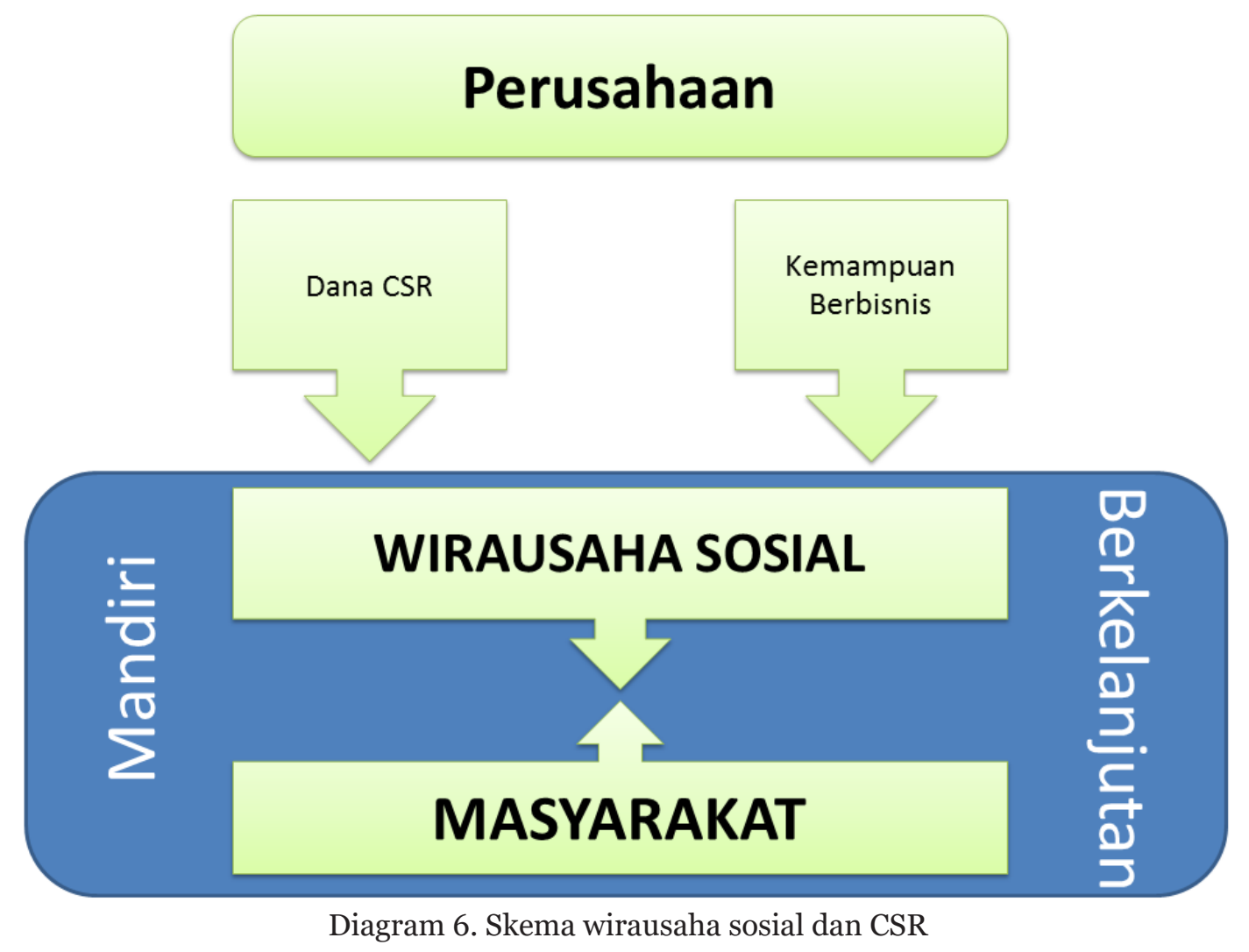

sebuah inkubator pengembangan lebih lanjut sebuah bisnis wirausaha sosial.

Dari diagram di atas, terlihat adanya timbal balik antara wirausaha sosial dan masyarakat, dimana masyarakat bukan hanya sebagai pelanggan bisnis, namun juga menjadi sumber daya manusia bagi bisnis AYOFest. Di sisi lain, seluruh keuntungan yang diperoleh dari masyarakat (pelanggan) akan kembali lagi ke masyarakat yang membutuhkan melalui program pelatihan secara gratis bagi remaja yang kurang mampu. Pada saat bisnis sudah mencapai taraf mandi- ri, dana dari donor maupun CSR tidak diperlukan lagi. Hal ini membuat ketergantungan pada pendanaan dari pihak lain hilang, serta memastikan kegiatan misi sosial tetap berjalan terus menerus.

\section{Simpulan}

Tren terus menurunnya donasi lembaga donor ke Indonesia merupakan sebuah fakta yang harus diterima semua orang. Lembaga Swadaya Masyarakat harus mulai merubah paradigma mengandalkan lembaga donor untuk dapat menjalankan misi sosial mereka. Solusi yang dapat dilakukan 
LSM adalah dengan mengubah diri menjadi sebuah lembaga wirausaha sosial (Social Entrepreneur). Mengubah sebuah LSM menjadi wirausaha sosial tentu saja tidak mudah, oleh karena itu dibutuhkan bantuan inkubasi dari perusahaan besar dan pendanaan melalui Corporate Social Responsibility untuk dapat memulai bisnis tersebut dan menjalankannya secara baik, mandiri dan memiliki keuntungan secara finansial.

Perusahaan besar yang memiliki dana CSR perlu lebih aktif dalam menyalurkan dana CSR tersebut seiring dengan menurunnya donasi dari luar negeri. Wirausaha sosial dapat menjadi alternatif utama bagi penyaluran dana CSR karena sebuah wirausaha sosial yang dikelola dengan baik dapat menjadi suatu lembaga sosial yang mandiri dan berkelanjutan. Bisnis yang dijalankan oleh sebuah wirausaha sosial tidak harus sejalan dengan misi sosial mereka, selama bisnis tersebut mampu berjalan mandiri dan menghasilkan keuntungan yang wajar.

\section{Referensi}

Kunitzky, R. (2011) Partnership Marketing. Missisauga: Wiley \& Sons Canada.

Borzaga, C, \& Defourny, J. (2001)

The Emergence of Social Enterprise.

London: Routledge.

Anheier, K. H. (2005). Nonprofit Organ- zations: Theory, Management, Policy. London: Taylor and Francis.

Getz, D. (2005). Event Management and Event Tourism, 2nd Edition. New York: Cognizant Communication Corporation.

Keys, T. (2009). Making the Most of Corporate Social Responsibility. Switzerland: McKinsey \& Company. 